\title{
In Defense of Judicial Review: A Reply to Professor Kramer
}

\author{
Erwin Chemerinsky ${ }^{\dagger}$
}

\section{INTRODUCTION}

Almost thirty years ago, I decided to go to law school because 1 wanted to be a civil rights lawyer. Although I have been a law professor for over two decades, at heart I am still very much the civil rights lawyer that I set out to be. Thus, as I read Professor Kramer's stunning new book about popular constitutionalism, ${ }^{1}$ I kept thinking about what his theory would mean for civil rights and civil liberties litigation. The answer is chilling. Popular constitutionalism would mean that courts would be far less available to protect fundamental rights. The rights of minorities would be largely left to the whims of the political majority with severe consequences for racial, ethnic, sexual orientation, and language minorities as well as criminal defendants, public benefits recipients, and others.

Literary theorists tell us that the reader always brings his or her experiences to a text. I have spent much of my time the last few years representing several individuals who are serving life sentences for shoplifting under California's "three strikes" law. In fact, I literally began reading Professor Kramer's manuscript on the plane returning from arguing one of those cases before the Supreme Court. My client, Leandro Andrade, received a life sentence, with no possibility of parole for fifty years, for shoplifting $\$ 153$ worth of videotapes. What would Professor Kramer's "popular constitutionalism" have meant for him? California's "three strikes" law was adopted by the state legislature and then reenacted by the voters through an initiative. This must be the epitome of "popular constitutionalism": the people expressing their interpretation of the Constitution. Indeed, the people of California, wittingly or not, were implicitly limiting the reach of due process and sanctioning a life sentence for shoplifting as within the bounds of the Eighth Amendment. Although

Copyright $(2004$ California Law Review, Inc. California Law Review, Inc. (CLR) is a California nonprofit corporation. CLR and the authors are solely responsible for the content of their publications.

$\dagger \quad$ Alston \& Bird Professor of Law, Duke Law School.

1. Larry D. Kramer, The People Themselves: Popular Constitutionalism and JUdiCIAL REVIEW (2004). 
Andrade lost 5-4 in the Supreme Court, ${ }^{2}$ under Professor Kramer's popular constitutionalism, Andrade would have had no chance at all. The people had already spoken, leaving no right to meaningful constitutional review under the Kramer theory. If this is what popular constitutionalism would mean, I want no part of it.

I have three main concerns with Professor Kramer's argument. First, he fails to adequately define the two key phrases in his argument, "popular constitutionalism" and "judicial supremacy." Dwelling in a realm of idealistic abstraction, Professor Kramcr avoids confronting the dramatic consequences of his theory for individual rights, constitutional restraints on state and local governments, and the balance of power among the branches. Second, Professor Kramer's theory devalues the role of judicial finality in interpreting and enforcing the Constitution by failing to recognize the essential, stabilizing effect of binding decisions by the judicial branch. Finally, popular constitutionalism, although advocated by many very prominent academics, ${ }^{3}$ risks foreclosing judicial protection for litigants who have nowhere to turn but the courts-litigants who are, by definition, unable the harness "popular" authority for their own constitutional interests.

\section{I \\ What Is "Popular Constitutionalism"?}

Professor Kramer's project is to advocate "popular constitutionalism" and to oppose "judicial supremacy." But he never offers a clear definition of what he means by these concepts. Notice the rhetoric of Professor Kramer's argument. He labels his theory "popular constitutionalism." Who could be against that? His attack is on "judicial supremacy." Who would favor these semantics? But, of course, two can play that game. This Reply is an opposition to "tyranny of the majority" and a defense of "judicial enforcement" of the Constitution.

Getting past the labels, what exactly is "popular constitutionalism"? Professor Kramer does not say. ${ }^{6}$ The closest he gets to a definition is the following statement:

2. Lockyer v. Andrade, 538 U.S. 63 (2003).

3. See, e.g., Richard D. Parker, "Here the People Rule": A Popular Cons? itutionalist Manifesto (I994); Mark Tushnet, Taking the Constitution Away from the Courts (1999); Jeremy Waldron, The Dignity of Legislation (1999).

4. Larry D. Kramer, Popular Constitutionalism, circa 2004, 92 Calif. L. Rev. 959, 1006 (2004).

5. Id. at 965 .

6. Nor do other scholars who advocatc popular constitutionalism provide a clear definition of this concept. Mark Tushnet, for example, argues that the elimination of judicial review will give rise to popular constitutionalism, but his most concrete definition is his statement: 
The assumption that final interpretive authority must rest with some branch of the government belongs to the culture of ordinary law, not to the culture of popular constitutionalism. In a world of popular constitutionalism, government officials are regulated, not the regulators, and final interpretive authority rests with the people themselves.

Additionally, Professor Kramer states, "In a system of popular constitutionalism, the role of the people is not confined to occasional acts of constitution making, but includes active and ongoing control over the interpretation and enforcement of constitutional law."8

But what does this mean? It is possible to imagine a range of possible definitions, each quite troubling. The absence of a definition is equally troubling. Failing to define his crucial concept-"popular constitutionalism"- - not only permits an abstract, glorified view of the public, it also obscures what is fundamentally at risk: weakening constitutional limits on the actions of elected and unelected officials; eroding constitutional protections for unpopular, marginalized groups; increasing discordant constitutional interpretations across the branches of the federal government and the states; and relegating constitutional interpretation by the judiciary to advisory status within the federal scheme.

Opposing judicial review in the name of an abstract faith in the public as authoritative interpreter of the Constitution risks that the diffuse, diverse public will express its constitutional will through mechanisms with substantial pitfalls. Though Kramer's Lecture ${ }^{9}$ leaves his vision of popular constitutionalism's mechanisms undefined, it is possible to surmise three forums for the public to voice its legal will: legislatures, popular initiatives, and the actions of public officials. Each has a dangerous Achilles' heel. Legislatures are heavily influenced by vested, special interests; popular initiatives are blunt, overinclusive legal instruments resulting from generalized campaigns that may be funded by veiled special interests; and public officials have no mandate, accountability, or democratic mechanism for expression of public "constitutional" will. Taking four plausible versions of Kramer's popular constitutionalism in turn, it is possible to better estimate the risks embedded in his theory.

The first possible interpretation of popular constitutionalism is the elimination of constitutional judicial review, that is, abolishing the author-

What is populist constitutional law? Throughout this book 1 have described it as a law oriented to realizing the principles of the Declaration of Independence and the Constitution's Preamble. More specifically, it is a law committed to the principle of universal human rights justifiable by reason in the service of self-government.

TUSHNET, supra note 3, at 181 .

7. KRAMER, supra note 1 , at 107 (emphasis in original).

8. Kramer, supra note 4, at 959.

9. Professor Kramer's Lecture, supra note 4, is drawn from his book, supra note 1.1 have used quotations from both to provide a more complete sense of his argument and my response to it. 
ity of courts to declare legislative or executive acts unconstitutional. Professor Kramer says that he does not favor the complete elimination of judicial review, but he frequently quotes Mark Tushnet, who has expressly advocated abolishing all constitutional judicial review in a book entitled Taking the Constitution Away from the Courts. ${ }^{10}$

An initial obvious problem with this approach is that it is unclear why the actions of unelected government officials-for example, police officers, prison guards, or zoning administrators-should be equated with popular constitutionalism. Eliminating judicial review would mean that courts could not declare the actions of these officials unconstitutional. But their decisions cannot be said to reflect popular judgments or to be a reflection of the democratic process.

Moreover, there are enormous problems with eliminating judicial review of legislative acts by elected officials. Constitutional interpretation would be transferred from an institution largely insulated from political pressure to one that is highly majoritarian. Checks and balances would be lost, most tragically in instances where the legislature simply chooses to ignore the Constitution at the expense of unpopular groups.

A second possible meaning of popular constitutionalism is that there would be no judicial review of voter initiatives or of the actions of elected officials. This, of course, would avoid the problem of equating the decisions of unelected officials with popular constitutionalism. But it shields much of popular law making as if it were popular constitutionalism. Having lived in California for the last twenty years, I have witnessed initiatives prohibiting government benefits for undocumented immigrants, abolishing affirmative action, and imposing life sentences for third-time offenders. While these ballot initiatives are examples of the people determining the content of the law, why should they be considered "popular constitutionalism," unless every enactment by an initiative meets that standard? Likewise, there is no reason to believe that everything a legislature does is an exercise of "popular constitutionalism." State laws often reflect the self-interests of legislators. Legislatures frequently enact laws to help in-state residents at the expense of out-of-staters. This is not really popular constitutionalism. Most laws passed by state legislators and ballot initiatives are examples of popular law making, not popular constitutionalism.

Shielding this law making from judicial review prevents natural flaws in the law-making process from being corrected. As actually used, initiatives cry out for more, not less, judicial review. " The many steps of legislative drafting and review are eliminated, often leading to poorly drafted, over-simplified language. Political minorities are especially vulnerable, as shown by California's initiatives eliminating benefits for undocumented

10. Tushnet, supra note 3 .

11. See Julian N. Eule, Judicial Review of Direct Democracy, 99 YALE L.J. 1503 (1990). 
immigrants and abolishing affirmative action. Even though such initiatives may be popular expressions of legal values, they can nevertheless result from underinformed decision making based on interest-led campaigns rather than principles. Similarly, though laws drafted by legislators may be technically superior to those drafted for initiatives, they are not immune from the self-interest of a particular group or the individual legislators.

A third possible meaning of popular constitutionalism is that it requires the judiciary to defer once another branch of government takes deliberate steps to overturn a court decision. In other words, the elimination of "judicial supremacy," which Professor Kramer espouses, ${ }^{12}$ would literally mean that the other branches and levels of government get the last word. The judiciary, including the Supreme Court, could speak, but other branches would be free to ignore the courts and functionally overrule their decisions. To be clear, this would mean that Southern states should have been free to interpret the Constitution for themselves and disobey judicial desegregation orders. Congress should have been accorded authority to overturn Miranda v. Arizona ${ }^{13}$ by statute. States with conservative majorities, such as Utah and Idaho, should be able to enact laws prohibiting abortion. The Supreme Court could say what it wanted, but there would be no finality to the Court's decisions. Everything decided by the judiciary essentially would solely be an "advisory opinion" to the other branches of government.

A fourth meaning of popular constitutionalism, and one which is consistent with the third, is that the other branches of government should develop mechanisms to convey their disagreement with court decisions. Professor Kramer expressly endorses this and mentions such congressional techniques as stripping jurisdiction from the courts and cutting the budget of the judiciary as a sanction for objectionable decisions. ${ }^{14}$ In other words, if Congress disagrees with controversial decisions, such as those concerning abortion or school prayer, Congress could preclude the courts from hearing such cases. In fact, Congress could enact a law that it knows is of dubious constitutionality, for example, prohibiting partial birth abortion, and include a provision prohibiting judicial review of the statute. Congress also could threaten the courts: if they acted in an unpopular way, they would be without funds.

Professor Kramer writes: "My purpose is not to defend or advance any particular version of popular constitutionalism. It is, rather, to present an overview of scholarly work on the matter and, in this way, to show the surprising breadth, strength, and coherence of the case for some form of

\footnotetext{
12. KRAMER, supra note 1, at 128-44.

13. 396 U.S. 868 (1969).

14. KRAMER, supra note 1 , at 232-33.
} 
popular constitutionalism." 15 While Professor Kramer's purpose may not be to "advance any particular version of popular constitutionalism," his failure to develop or defend a particular vision (even his own) means we are confronting only an abstract concept. As an abstraction it sounds great; "power to the people" always has appeal. But it is crucial to define exactly what popular constitutionalism means as a real world approach to government and the balance of power among the branches. Perhaps Professor Kramer would adopt one of the above definitions of "popular constitutionalism." Maybe he has a different vision. But as presented by Professor Kramer, popular constitutionalism could ultimately insulate unconstitutional conduct by legislators and elected or unelected officials from any form of meaningful review. The remainder of this Reply suggests that while advocating for popular control of the Constitution may seem attractive, when we wish to protect the rights of real people in real situations, judicial finality is essential to preserving the freedoms promised by the Constitution.

II

\section{The IMPORTANCE OF Judicial FinaLity}

There are several gaps and fallacies in Professor Kramer's argument for popular constitutionalism. If we remove popular constitutionalism from the realm of the abstract, these gaps and fallacies emerge. We realize, for example, that Professor Kramer's argument relies almost exclusively on an overly optimistic view of the elected branches of the federal government. In his view, the executive and legislative branches are nearly direct proxies for the people, faithfully interpreting and implementing the Constitution on their behalf. The Supreme Court is to defer to the other branches: since it is more removed from the people, its proxy power is more suspect. But this simple construct leaves out key players such as state and local governments, lower courts, and unelected officials. As I indicated in Part I, these players cannot be ignored if we are to get a true sense of the impact popular constitutionalism could have on civil rights.

First, Professor Kramer focuses only on the federal government and its fidelity to the Constitution; he gives virtually no attention to what popular constitutionalism would mean when it comes to state and local governments. Professor Kramer extols the deliberative process in Congress and even suggests that it may be better than the Supreme Court's decision-making process. ${ }^{16} \mathrm{I}$ believe that Professor Kramer has an idealized image of the federal legislative process - one that is dramatically different from what public choice theorists have been telling us for decades. Common sense combined with extensive research tells us that Congress

15. Kramer, supra note 4, at 961 .

16. KRAMER, supra note 1, at 239-42. 
often acts in response to direct pressures from special interest groups. No one suggests that judicial decision making bows to the same forces. A basic difference between the judicial and the legislative processes is that the former is supposed to involve decisions based on reasoned arguments; the latter is accepted as involving decisions based entirely on political pressures and special interests. This is not to say that judicial review is apolitical in the sense that it is value free, but rather, that judicial review is not the product of lobbying or direct pressure from special interests.

By focusing exclusively on restricting judicial review of actors by the federal government, Professor Kramer ignores the importance of having an authoritative interpreter of the Constitution to unify and ensure the integrity of state and local law. By foreclosing judicial review of federal actions in the name of popular constitutionalism, Kramer has implicitly insulated state and local governments from the same review-they arc, after all, arguably even closer to the people. Perhaps Professor Kramer only wants popular constitutionalism to apply when it comes to judicial review of the actions of the other branches of the federal government. However, nothing in his book suggests or even implies such a limitation. Quite the contrary, he frequently criticizes decision making by "elites." ${ }^{17}$ Many have defended federalism on the ground that statc and local governments are closer to the people and thus more responsive to public needs and concerns. ${ }^{18}$ Actions by state and local governments would thus come even closer to popular constitutionalism than choices by Congress.

Empowering state and local governments to disregard Supreme Court decisions is a truly frightening notion, as disobedience to unpopular rulings would be inevitable. States would be able to choose not to follow Bill of Rights provisions, thereby ignoring the Supreme Court's incorporation decisions applying the Bill of Rights to the states. As pointed out in Part I, states could ban abortion and ignore the Supreme Court's rulings in Roe v. Wade $^{19}$ and Planned Parenthood v. Casey. ${ }^{20}$ Local school boards could disobey the Supreme Court's decisions banning prayer in schools. Indeed, local governments would be free to pick and choose among Supreme Court rulings, following those that it liked and disregarding those that were unpopular with its constituents.

State and local governments are also less likely to bear the attributes of fidelity to the Constitution. Long ago, James Madison expressed concern over factions, which are much more likely, in his view, to capture local governments than the national government. He thought that the

\footnotetext{
17. KRAMER, supra note 1, at 110.

18. See, e.g., David L. Shapiro, Federalism: A Dialogue 92 (1995); Andrzej Rapczynski, From Sovereignty to Process: The Jurisprudence of Federalism After Garcia, 1985 SUP. CT. Rev. 341,

19. 410 U.S. 113 (1973).

20. 505 U.S. 833 (1992).
} 391. 
competition of factions at the national level would be an important protection of liberties. ${ }^{21}$ Moreover, without the check of final judicial decision making, state and local governments could freely act to help their own citizens at the expense of nonresidents. For example, under popular constitutionalism, there would be no dormant commerce clause to stop states from discriminating against out-of-staters and burdening interstate commerce. Nor would there be any limit on the ability of states to burden the right to travel by discriminating against out-of-staters. ${ }^{22}$

Second, Professor Kramer focuses only on the Supreme Court and does not discuss the consequences of changing the power of the courts at all levels. Eliminating or reducing constitutional judicial review would take the power away from all of the lower federal courts and, seemingly, all state courts as well. Popular constitutionalists make no argument as to why state judicial review is any different than the practice in the federal courts; every argument for popular constitutionalism applies equally as a criticism of state courts.

Assessing the desirability of judicial review requires accounting for the countless decisions by courts other than the Supreme Court, that enforce the Constitution and invalidate constitutional violations by governments and government officials. Some of the most egregious actions never make their way to the Supreme Court once they have been struck down by lower courts. Professor Kramer's failing is common to much of the scholarship advocating popular constitutionalism. For example, Gerald Rosenberg's much-cited book, arguing that courts fail to make a difference in changing society, looks only to the Supreme Court, ignoring lower courts and the impact of their rulings. ${ }^{23}$ It is easy to portray a single, ninemember body as an antipopulist oligarchy. It is harder to do so with an intricate system of state and local courts that all have some role in protecting the constitutional rights of the people.

Third, Professor Kramer's popular constitutionalism, at most, justifies eliminating (or reducing) judicial review of the actions of elected officials, but his theory would eliminate (or reduce) judicial review of the actions of unelected officials as well. Much actual governance in the United States is done by unelected officials and regulatory agencies at all levels of government. As stated in Part I, popular constitutionalism stresses the desirability of majority rule, yet it would seemingly extend to acts by these unelected officials whose decisions meet no definition of majoritarianism. Even if

21. James Madison, Speech in the Federal Convention on Factions (June 6, 1787), in JAMES Madison, Writings 92, 92-93 (Jaek N. Rakove ed., 1999); The Federalist No. 10 (James Madison) (discussing factions and their risk to the public good).

22. See, e.g., Saenz v. Roe, 526 U.S. 489 (1999).

23. Gerald N. Rosenberg, The Hollow Hope: Can Courts Bring About Social Change? (1991) (focusing primarily on desegregation, abortion, and self-incrimination decisions from the Supreme Court). 
one could accept the popular constitutionalists' trust in the majoritarian process, it seems absurd to say that police officers or prison guards or zoning board members will have compliance with the Constitution at the forefront of their concerns.

Professor Kramer might argue that elected officials ultimately oversee the actions of unelected officials, and thus there is majoritarian control. This, too, is untenable. Even if electoral accountability exists on paper, there is often little actual control over actions by the police in particular cases, or of prison guards, or of the myriad regulatory agencies that exist at all levels of government. As I read Professor Kramer's book, I kept wondering what popular constitutionalism would mean for the huge body of criminal procedure decisions. Seemingly, the Fourth, Fifth, and Sixth Amendments, like the rest of the Constitution, would be largely left to the political process to interpret and enforce. Will we really feel secure giving police officers the power to define what is a constitutionally appropriate search with only the security of knowing that their actions may someday be reviewed by a police chief who may someday be called to task by a mayor who was elected by the people?

Fourth, Professor Kramer assumes that because the elected branches sometimes protect liberties, they always can be trusted to do so. Professor Kramer, for example, points to the 1964 Civil Rights Act as showing the willingness of Congress to advance equality. ${ }^{24}$ Almost every state, however, has antidiscrimination laws that are often even more protective than federal statutes. Professor Kramer's theory is based on a romantic assumption that elected officials can be trusted to advance the Constitution's values for all people all the time.

Certainly, popular constitutionalists are correct that this sometimes occurs. But at many other times tyranny of the majority prevails. Laws enforcing segregation existed throughout the South and likely would have lasted long beyond their invalidation by the Supreme Court if the change had been left to the political process. ${ }^{25}$ Throughout history, majorities have persecuted racial, religious, and political minorities. This, too, is "popular constitutionalism," but hardly the kind that any of us wants to preserve or promote.

Of course, these criticisms of Professor Kramer's theory do not provide an affirmative case for judicial review. Obviously, a full defense of judicial review is far beyond the scope of this Reply. ${ }^{26}$ But my vision of the role of the judiciary in American democracy is radically different from

\footnotetext{
24. Kramer, supra note 4, at 985.

25. Erwin Chemerinsky, Wrong Questions Get Wrong Answers: An Analysis of Professor Carter's Approach to Judicial Review, 66 B.U. L. REv. 47, 51 (1986).

26. Over fifteen years ago, I attempted to provide a defense for eonstitutional judieial review. See ERWIN ChEMERINSKY, INTERPRETING The CONSTITUTION (1987).
} 
Professor Kramer's. I believe that it is desirable to have an institution, largely insulated from direct majoritarian control, decide the meaning of the Constitution. Subject to overruling only by constitutional amendments and its own later decisions, the federal judiciary should have the last word in interpreting and enforcing the Constitution.

In part, such "judicial supremacy" is desirable to ensure that the limits contained in the Constitution have meaning. This was the argument made for judicial review long ago by Chief Justice John Marshall. ${ }^{27}$ Marshall wrote: "The question, whether an act, repugnant to the constitution, can become the law of the land, is a question deeply interesting to the United States; but, happily, not of an intricacy proportioned to its interest." 28 Marshall argued that the Constitution imposes limits on government powers and that these limits are meaningless unless subject to judicial enforcement. Borrowing from Alexander Hamilton's Federalist No. 78, the Court stated: "The powers of the legislature are defined and limited; and that those limits may not be mistaken or forgotten, the constitution is written."29 Thus, Chief Justice Marshall concluded in words that Professor Kramer would reject: "It is, emphatically, the province and duty of the judicial department, to say what the law is." 30

There are times when Professor Kramer's avowed trust in the people is misplaced. The famous Carolene Products footnote got it exactly right: when it comes to politically powerless minorities, or ensuring the proper workings of the political process, or safeguarding fundamental rights, the political process - and popular constitutionalism - cannot be trusted. ${ }^{31}$ The absence of judicial review or judicial supremacy dramatically reduces, if not eliminates, the checks on the persecution of minorities. Minorities should not need to depend on the majority for their protection.

Ultimately, I believe that it is desirable to have an institution, like the Supreme Court, to decide, in interpreting the Constitution, the content of society's most precious values and protect them from legislative interference. I believe that it was a good thing that the Court could protect abortion rights when most states clearly were not about to do so. It was a good thing that the Court could invalidate state laws prohibiting private consensual homosexual activity and invalidate the death penalty for the mentally retarded. All of this seemingly would be lost with Professor Kramer's popular constitutionalism.

27. Marbury v. Madison, 5 U.S. (1 Cranch) 137 (1803).

28. Id. at 176 .

29. Id. at 176; see also The Federalist No. 78, at 446-469 (A. Hamilton) (Clinton Rossiter ed., $1961)$.

30. Marbury, 5 U.S. at 177.

31. See United States v. Carolene Products, 304 U.S. 144, 152 n.4 (1938). 
III

\section{The Dangers of Popular Constitutionalism}

Professor Kramer, of course, is not the only advocate of popular constitutionalism. Many prominent scholars who would be regarded as progressive are advocating this approach, including Mark Tushnet, Jeremy Waldron, Richard Parker, Robert Post, and Reva Siegel..$^{32}$ Why are progressives turning against the courts? Does it matter?

I believe that some progressives are turning against the courts at this time because the Supreme Court and the lower federal courts are dominated by conservative judges and are likely to remain that way for the foreseeable future. There is understandable concern that conservative courts will invalidate progressive legislation, just as occurred in the Lochner era. For example, Robert Post and Reva Siegel persuasively show that the current Supreme Court has unduly limited the powers of Congress to advance individual rights in its decisions restricting the scope of Congress' powers under Section 5 of the Fourteenth Amendment. ${ }^{33}$ I share their criticism of these recent Supreme Court decisions, such as City of Boerne v. Flores, ${ }^{34}$ which dramatically narrowed the scope of Congress' authority under Section $5 .{ }^{35} \mathrm{I}$ also share their concern that conservative-dominated courts will threaten progressive legislation in the years to come.

But I question whether popular constitutionalism is necessary to criticize these recent Court rulings. The Court's decisions can be attacked on their own terms, as a misguided interpretation of Section 5 and an undue restriction of legislative power under a specific provision intended to empower Congress to enforce the Constitution. There need not be an elimination or reduction of the overall power of the courts to overturn these decisions as misguided.

Professor Kramer suggests that the Warren Court was an aberration and that defenders of judicial review mistakenly assume that its protection of individual rights is typical of the Supreme Court. ${ }^{36}$ But one need not turn to the Warren Court to see how the Supreme Court routinely protects individual rights through judicial review. Critics of judicial review ignore the extent to which even the conservative Rehnquist Court has advanced individual rights. In its most recent Term, the Court invalidated a state law

32. See, e.g., PARKer, supra note 3; TUSHNET, supra note 3; WALDRON, supra note 3; Robert C. Post \& Reva B. Siegel, Equal Protection by Law: Federal Antidiscrimination Legislation After Morrison and Kimel, 110 YALE L.J. 441 (2000); Robert C. Post \& Reva B. Siegel, Protecting the Constitution from the People: Juricentric Restrictions on Section Five Power, 78 1ND. L.J. 1 (2003).

33. Post \& Siegel, Equal Protection by Law, supra note 32; Post \& Siegel, Protecting the Constitution from the People, supra note 32.

34. 521 U.S. 507 (1997) (finding the Religious Freedom Restoration Act of 1993 an unconstitutional overreach of congressional power).

35. See Erwin Chemerinsky, The Religious Freedom Restoration Act is a Constitutional Expansion of Rights, 39 WM. \& MARY L. REv. 601 (1998).

36. KRAMER, supra note 1 , at 233. 
prohibiting private consensual homosexual activity ${ }^{37}$; declared a death sentence unconstitutional for ineffective assistance of counsel ${ }^{38}$; held that the retroactive extension of a statute of limitations for sexual molestation is an impermissible ex post facto law ${ }^{39}$; and ruled that public colleges and universities may engage in affirmative action and use race as one factor in admissions decisions to benefit minorities. ${ }^{40}$ No one would suggest that the Rehnquist Court is the reincarnation of the Warren Court. Yet, even this Court, at times, has significantly advanced individual freedom.

The real risk of popular constitutionalism is that it will undermine judicial review in the long term. How judicial review is discussed by scholars today will influence how it is practiced tomorrow. Liberal criticism of the Lochner Court led to a Supreme Court that was highly deferential to the government for at least a decade and a half after President Franklin Delano Roosevelt appointed a solid Democratic majority. Conservative criticism of the Warren Court led to the Burger and Rehnquist Courts as well as the originalist philosophy of judicial review, which has real influence on today's Supreme Court. My fear is that popular constitutionalism will lead future progressive judges to practice judicial restraint at the expense of enforcing the Constitution to advance liberty and equality.

Progressive constitutional scholars need to focus on defending a vision of constitutional law that will advance equality and basic human rights. We need to defend the courts' unique role in accomplishing this, rather than turning against the judiciary. The emphasis should be on describing and defending what the Constitution's guarantees should mean. The challenge for progressives is to articulate an alternative vision of judicial review, one different from those offered by conservatives or popular constitutionalists, one in which courts protect dignity, enhance freedom, and further equality. Perhaps these arguments will not be accepted today, but this generation's scholarship will powerfully influence what happens tomorrow.

\section{CONCLUSION}

I have a request for those such as Professor Kramer who advocate popular constitutionalism: ask civil rights and civil liberties lawyers what they think of such an approach to judicial review. Professor Kramer provides an elegant theory, but one that would be tragic in the real world. In

37. Lawrence v. Texas, 539 U.S. 558 (2003).

38. Wiggins v. Smith, 123 S. Ct. 2527,2534 (2003) (holding that the failure of an attorney to investigate and present mitigating evidence concerning a capital defendant's background is ineffective assistance of counsel).

39. Stogner v. California, 539 U.S. 607 (2003).

40. Grutter v. Bollinger, 539 U.S. 306 (2003). 
Professor Mark Tushnet's book advocating popular constitutionalism and the end of judicial review, I found this statement most telling: "My wife [Elizabeth Alexander] is Director of the National Prison Project of the American Civil Liberties Union. She disagrees with almost everything I have written in this chapter [entitled 'Against Judicial Review'].",41 Surely this is not because prisoners' claims are doing very well in the courts right now. Rather, it is because a prisoner's only hope often lies in the courts. It is highly unlikely that the majority of people, in their exercise of popular constitutionalism, will act to protect prisoners and their rights.

Fundamental human rights, the rights of minorities, and the rights of those unpopular in society should not depend on the wishes of the majority. Stripped of all of its abstract rhetoric, popular constitutionalism would have exactly this effect in eliminating or greatly reducing the role of the courts. However well-intentioned, popular constitutionalism is profoundly misguided.

41. Tushnet, supra note 3, at 174. 
